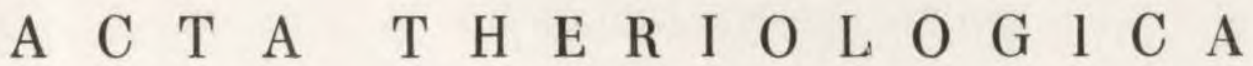 \\ VOL. X, 4: 55-78. \\ BIAŁOWIEŻA \\ 15.VIII. 1965
}

\author{
Danuta C Z A P L I N S K A, Bogdan C Z A P L I N S K I, \\ Maria R U TKOWSKA \& Danuta ŻEBROW SKA
}

\section{Studies on the European Hare. IX. Helminth Fauna in the Annual Cycle}

[With 10 Figs. \& 4 Tables]

\begin{abstract}
The study deals with helminths of the alimentary tract and lungs of 706 hares from the Poznań province, examined over a period of 15 consecutive months (from December 1958 to February 1960), numbering from 34 to 54 individuals a month. Helminths (Trematoda, Cestoda and Nematoda) were discovered in 671 hares $\left(95^{\circ} \%\right)$. The percentage of infested animals varied in different months from 91 to $100 \%$. Nine species of parasites were found: Fasciola hepatica in $2.2 \%$ of the hares, Andrya rhopalocephala in $1.4 \%$, Mosgovoyia pectinata in $8.7 \%$, Trichostrongylus retortaeformis in $79.4 \%, T$. medius and Haemonchus contortus in $0.1 \%$, Graphidium strigosum in $3.9 \%$, Protostrongylus commutatus in $1.1 \%$ and Trichuris sylvilagi in $72.8 \%$ of the hares. Morphological observations refer to the following: $F$. hepatica, A. rhopalocephala, T. retortaeformis, $P$. terminalis and T. sylvilagi. Variations in the intensiveness and extensiveness of invasion were examined over the year's cycle. In the case of tapeworms strobiles with mature oncospheres were found at different times of the year, which is evidence of the absence of winter destrobilation. Three species were found throughout the year: $M$. pectinata, T. retortaeformis and T. sylvilagi. Analysis was made of how invasion of different species of helminths depended on the sex and age of the hares, greater intensiveness and extensiveness of invasion by $T$. sy'vilagi being found in pregnant than in non-pregnant females. Analysis of the co-occurrence of helminths in one individual host showed that the species of parasites examined do not exclude each other.
\end{abstract}

\section{INTRODUCTION}

Studies made so far on the helminth fauna of the hare in areas within the present frontiers of Poland are limited to three publications: $\mathrm{Cz}$ a r now s ki \& Wit kowski (1954), Drygas \& Piotrowski (1955a and 1955b). The first of these dealt with pneumonia caused by Protostrongylus terminalis, the second with the morphology of Trichuris sylvilagi, while the third referred to helminths of the alimentary tract of 617 hares examined over a period of three consecutive years, but during the 
shooting season. The investigations revealed the presence of the following species: Mosgovoyia pectinata, Andrya rhopalocephala, Trichostrongylus retortaeformis, Graphidium strigosum, Protostrongylus terminalis and Trichuris sylvilagi. In comparison with the publications of earlier authors our investigations constitute an extension of our knowledge of hare helminth fauna in Poland due to the following species having been added: Fasciola hepatica, Haemonchus contortus and Trichostrongylus medius. The two last species were found for the first time in the hare in two single cases and were probably accidental parasites of the host, and were ti:erefore not taken into consideration in analysing each of the species.

\section{MATERIAL AND METHODS}

The material used in the present study consisted of 706 hares from the Poznan province, from 34 to 54 specimens being examined every month during the period from December 1958 to February 1960 inclusive. The sex of 592 and age of 572 specimens was determined (young, one-year old and older hares), which had been shot during the period from January to December 1959. It is for this reason that the analysis of the occurrence of each species of parasite in males and females in different age groups refers only to these 572 hares, and not to the total number of specimens.

Examinations included the alimentary tract (oesophagus, stomach, small intestine, liver together with gall bladder, large intestine) and the heart, lungs and trachea. Helminthological dissection, collection, fixing and staining of the material obtained were carried out in accordance with generally accepted principles. The intensiveness of invasion was defined directly by counting all the parasites, or in cases of exceptionally intense invasion, by counting the parasites only in a defined sample of the contents of a whole section of the intestine examined.

The material at our disposal made it possible to analyse the state of invasion by parasites over the course of a whole year and the infestation of pregnant females in comparison with non-pregnant ones, which was not possible in the case of the study made by Drygas \& Piotrowski (1956b).

\section{DETAILED DESCRIPTION}

\section{Trematoda}

\section{Fasciola hepatica $\mathrm{L}$ in n a e u s, 1758}

Morphology: The anatomical structure of 41 specimens of parasites did not differ from that of specimens found in the liver of cattle.

Localisation: bile ducts of the liver.

Intensiveness and extensiveness of invasion: $F$. hepatica was found in 16 hares out of a total of 706 examined $(2.2 \%)$ in numbers from $1-6$ trematodes in one hare. The invasion of the fluke over the yearly cycle is shown in table 1. As can be seen from this table, we found $F$. hepatica in single specimens of hares from December 1958 to June 1959, after which an interval took place in the occurrence of the parasite, which we found only in one hare in November. 
Dependence of invasion on the sex and age of the hares. Analysis of this question did not provide sufficient evidence for drawing conclusions, on account of the very slight extensiveness and intensiveness of infestation. In young hares (up to one years old) Fasciola hepatica was found in two males ( 2 and 6 trematodes) in 1 female and 3 male one-year old hares ( $1-2$ trematodes) and in 9 older hares, 4 males and 5 females (1-6 trematodes).

Dependence of invasion on sex was examined in 309 males, of which 9 were infested $(2.91 \%)$ and in 263 females, Fasciola hepatica being found in 6 of these individuals $(2.28 \%)$, among which were 4 pregnant females. Intensiveness of invasion by Trematoda in males and females fluctuated in similar limits, i.e. from 1 to 6 individuals in one host.

Co-occurrence of $F$. hepatica with other species of helminths. Parasitic worms accompanying invasion by $F$. hepatica were found to be as follows: Trichostrongylus retortaeformis - in 3 hares, Trichuris sylvilagi - in one hare, Trichostrongylus retortaeformis and Trichuris sylvilagi in 11 hares, Trichostrongylus retortaeformis, Trichuris sylvilagi and Protostrongylus terminalis - in one hare. The other species were not found to occur together with $F$. hepatica. Mixed invasion with $T$, retortaeformis and $T$. sylvilagi was most frequently found.

\section{Cestoda}

2. Andrya rhopalocephala ( $\mathrm{R}$ i e h $\mathrm{m}, 1881$ ), $\mathrm{R}$ a illi e t, 1893.

Morphology. The body length of adult individuals containing eggs with oncospheres varies from 60 to $153 \mathrm{~mm}$ (after S p a s k y, 1951) up to 800 $\mathrm{mm}$ ). The dimensions and shape of each of the organs come within the limits variation given by S p a s s k y (1951). An exception to this is formed by the dimensions of the oncospheres, the diameter of which, in material preserved and submerged in Canadian balsam, was from $11-19 \mu$, with a mean value of $15 \mu$. This constitutes a sort of intermediate form of the sizes of the oncospheres $A$. cuniculi $(18 \mu)$ and $A$. rhopalocephala $(10 \mu)$ given by S pas s k (1951). The dimensions of the whole eggs of both species are, according to $\mathrm{Sp}$ a s s ky, almost identical in the case of $A$. cuniculi $48-60 \mu$, and $52-60 \mu$ for $A$, rhopalocephala. In our material the dimensions of the eggs varied from 41 to $64 \mu$. The question of the situation and shape of the prostate gland which, according to S passky's drawings is long and slender in shape in A. rhopalocephala and short and almost round in $A$. cuniculi, deserves attention. We found in our material that the shape and size of this gland frequently varies considerably, even in different segments of the same specimen of tapeworm. Differential diagnosis between $A$. rhopalocephala and $A$. cuniculi is based on the 


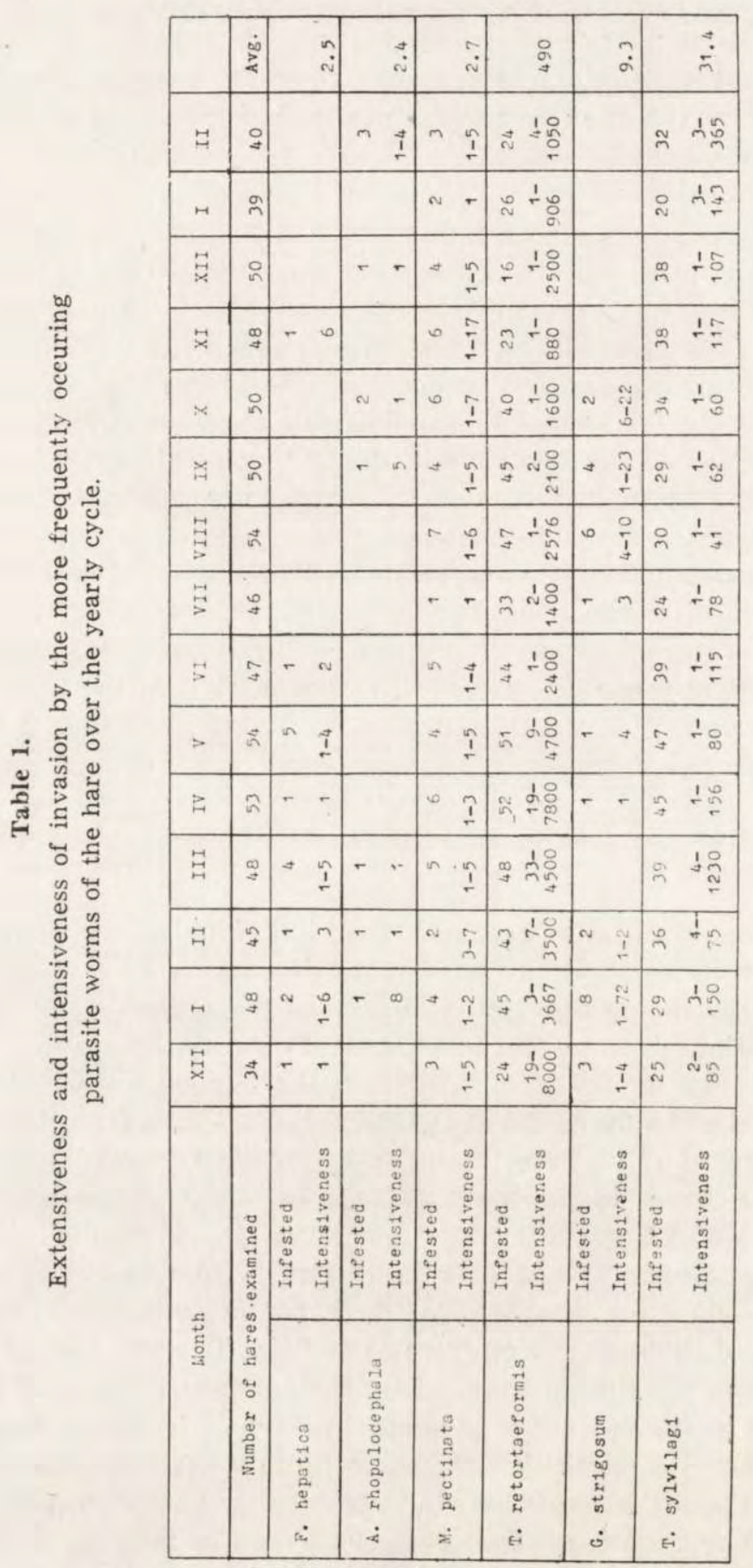


usually greater body dimensions, smaller scolex and larger suckers in $A$. cuniculi. The differences given, in addition to these, in the dimensions of the oncospheres and in the shape and size of the prostate gland would not in the light of our investigations appear to be of any value in diagnosis.

Localisation: small intestine.

Intensiveness and extensiveness of invasion. A. rhopalocephala was found in 10 out of the total number of 706 hares examined $(1.4 \%)$, varying in numbers from $1-8$ individuals in one hare. The invasion of this tapeworm over the yearly cycle is shown in table 1 , from which it will be seen that $A$. rhopalocephala occurred in single cases only during the autumn, winter and early spring months. The frequence of occurrence of this tapeworm suggests, however, that it was entirely accidental. Nevertheless the fact that tapeworms with whole strobilae, often containing mature oncospheres, were found in all periods, is worthy of note.

Dependence of invasion on the sex and age of the hares. Sex and age were determined in only 7 hares out of the 10 specimens infested. We found $A$. rhopalocephala in 3 females (including one pregnant female) and in 4 males. There were no young specimens amongst the infested hares, while 3 were one year old and 4 were old individuals.

Co-occurrence of $A$. rhopalocephala with other species of helminths. Parasite worms accompanying the invasion of $A$. rhopalocephala proved to be Trichostrongylus retortaeformis and Trichuris sylvilagi in 9 hares, Trichostrongylus retortaeformis, Trichuris sylvilagi and Mosgovoyia pectinata in one hare.

\section{Mosgovoyia pectinata (G o e ze, 1782), S pas k k y, 1951}

Localisation: small intestine.

Intensiveness and extensiveness of invasion. $M$. pectinata was found in 62 out of 706 hares examined $(8.7 \%)$. Table 1 illustrates the invas on of this tapeworm over the yearly cycle. As can be seen from the table this tapeworm occurs throughout the whole year, and it is noteworthy that whole strobilae with mature oncospheres were found throughout the whole year. In comparison with the results of the investigations made by D ry g a s \& P i o trow ski (1955b) during winter periods only the total extensiveness of invasion by tapeworms found in our material is almost identical. In different months of the year the percentage of hares infested by $M$. pectinata exhibits fluctuations, in our opinion insignificant, from 4.4 to $12.9 \%$, which point to the persistent vitality of the tapeworm. It was only in July 1959 that we found 1 infested hare out of 46 examined $(2.1 \%)$, which might, however, be entirely accidental. D ry gas \& Pi otrow$\mathrm{s} \mathrm{k}$ i's conclusion that invasion is markedly reduced in January, confirming the investigations made by $\mathrm{R}$ i e $\mathrm{h} \mathrm{m}, 1881$; $\mathrm{S} \mathrm{t} \mathrm{un} \mathrm{k} \mathrm{a} \mathrm{r} \mathrm{d,} \mathrm{1934;} \mathrm{Z} \mathrm{e}-$ 
d e r, 1800; would not seem to be thoroughly justified. In their own material the percentage of infested hares varies in December in three successive shooting season from 0 to $16.2 \%$, while in November 1951 the percentage of hares invaded by this tapeworm was slightly lower $(7.9 \%)$ than in January $1953(8.1 \%)$. While it is true that in our material we can find a slight decrease in extensiveness of invasion of $M$. pectinata in January, expressed in comparison with December by a difference of $0.5 \%$ and $3.1 \%$ in consecutive seasons, yet we consider these differences as non-significant in view of the variations in extensiveness of invasion over 15 successive

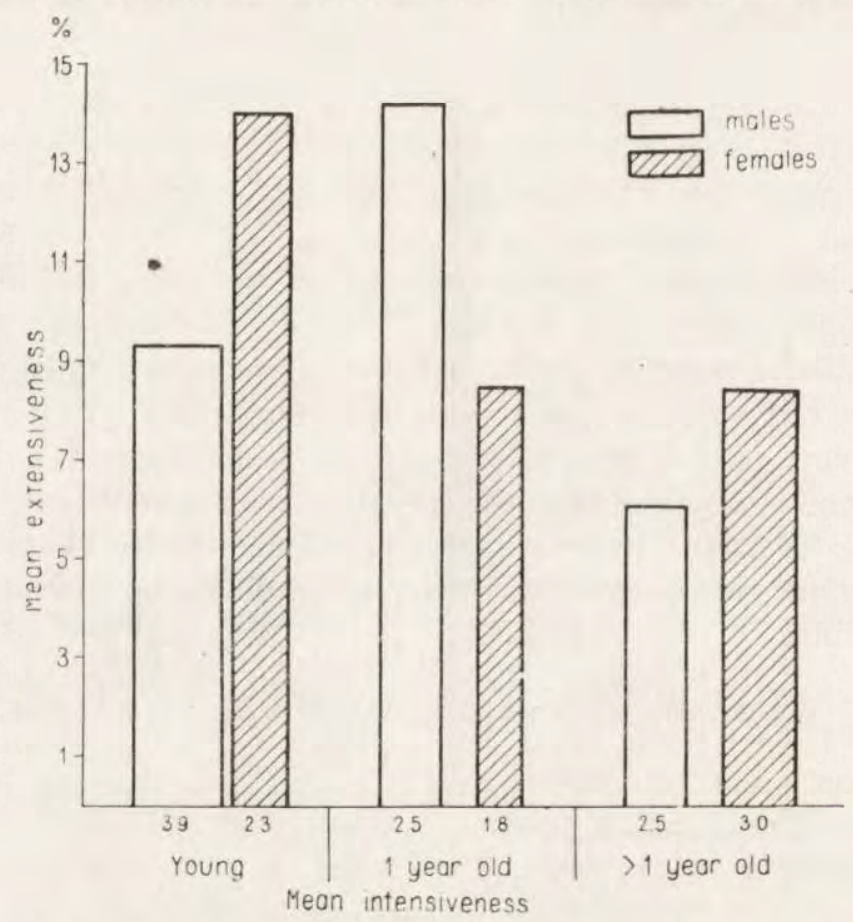

Fig. 1. Extensiveness and intensiveness of invasion by Mosgovoyia pectinata depending on the sex and age of the hares.

months illustrated in Table 1. The mean intensiveness of invasion was found in our material to be slightly above (2.7) the results of the above author's examinations, in which they found a mean figure of 2.0 tapeworms in each infected hare.

Dependence of invasion by $M$. pectinata on the sex and age of the hare. The extensiveness of invasion in males is $9.0 \%$, that is, slightly lower than in females, for whom the figure is $9.8 \%$. The mean intensiveness of invasion, on the other hand, is slightly higher in males -2.9 specimens to each infested host - than in females, for which this value is 2.5 . These differ- 
ences would not seem to be important, since an analysis of infestation by $M$. pectinata in hares of both sexes and different age classes reveals a different arrangement of figures, illustrated in Fig. 1. As shown by this figure and by previous data, the extensiveness of invasion is not in complete agreement with its intensiveness. The maximum extensiveness occurs in young females and males one year old, being respectively 14.0 and $14.2 \%$ and the minimum in old males $(6.1 \%)$. Maximum intensiveness of invasion was noted in young males (mean number 3.9 tapeworms per 1 hare), and minimum in females one year old (mean number 1.8 tapeworms). Fig. 1 shows the differences in the values expressing intensiveness and extensiveness of invasion in males and females of different ages. In view of the small amount of material available these differences would not appear to provide grounds for drawing definite conclusions. For the same reasons it is also difficult to say whether the pregnancy of females affects invasion by $M$. pectinata. The fact may, however, be recorded that out of the 86 pregnant females examined 5 individuals $(5.8 \%)$ were infested by this tapeworm, while we found 10 infested specimens, that is, almost $9 \%$ out of the 112 non-pregnant females from the same period, from January to September. (The total percentage of all the non-pregnant and infested females examined was even higher, $11.3 \%$ ).

Co-occurrence of $M$. pectinata with other species of helminths. Among the 62 hares infested by above tapeworm one hare was found to be infested by Mosgovoyia pectinata only. Helminths accompanying the invasion of this parasite were found to be: Trichostrongylus retortaeformis - in 3 hares, Trichuris sylvilagi - in 13 hares, Trichostrongylus retortaeformis and Trichuris sylvilagi - in 40 hares, Trichostrongylus retortaeformis and Protostrongylus terminalis - in one hare, Trichostrongylus retortaeformis, Trichuris sylvilagi and Graphidium strigosum in one hare, Trichostrongylus retortaeformis, Trichuris sylvilagi and Protostrongylus terminalis - in 1 hare, T. retortaeformis, T. sylvilagi and Andrya rhopalocephala in 2 hares. As shown by the figures mixed infestation of $M$. pectinata with $T$. sylvilagi and $T$. retortaeformis occurs most frequently $(64.6 \%)$.

\section{Nematoda}

4. Trichostrongylus retortaeformis ( $\mathrm{Z}$ e d e r, 1800), L o o s S, 1905

Morphology. The morphological structure of the specimens we found agreed with the descriptions so far given. We several times found specimens, however, with swelling of the cuticle on the anterior end of the body (Fig. 2) and undulating course of the pharynx.

Localisation: small intestine, accidentally the stomach. 
Intensiveness and extensiveness of invasion. We found $T$. retortaeformis in 561 hares out of 706 examined, i.e. $79.4 \%$, in numbers varying from $1-8000$ in one hare. The invasion of this nematode over the yearly cycle is illustrated in table 1 , from which it can be seen that $T$. retortaeformis occurs abundantly throughout the whole year. Intensiveness and extensiveness of invasion, determined jointly for all the hares examined, irrespective of their age and sex, are given in Fig. 3. Both the numerical data and the figure show that fluctuations in the intensiveness and extensiveness of invasion exist which do not coincide with each other. Can these fluctuations be considered as connected with the season of the years? Extensiveness of invasion is maintained on a high level throughout the whole year and would not seem to point to any distinct connection with the
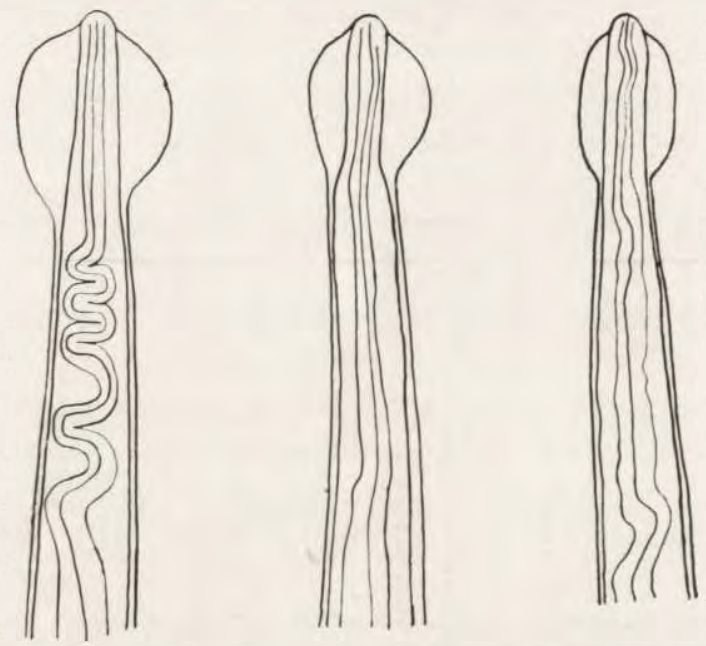

Fig. 2. Anterior end of the body of $T$. retorfaeformis with swellings of the cuticle.

seasons. It is true that in December, January and February $1959 / 60$ a decrease was observed in the extensiveness of invasion (respectively $32 \%, 66 \%$ and $60 \%$ ) but in the same months of the previous year 1958/59 extensiveness of invasion was maintained on the same level as in the spring-summer period. The phenomenon of the seasonal character of invasion by $T$. retortaeformis, on the other hand, can be observed by means of comparison of fluctuations in the mean intensiveness of invasion, which reaches a peak in April and exhibits an uneven decrease in the summer, reaching a minimum in January 1960 . The mean intensiveness of invasion in January of the previous year, 1959, was, however, far higher, although it reflected a distinct tendency to decrease, reaching a minimum in $\mathrm{Fe}-$ bruary 1959. In general intensiveness of invasion in the winter months of $1958 / 59$ was not only far higher than in the same months in $1959 / 60$ but 
also exceeded the intensiveness of invasion by the parasite in the summer months. It must be supposed that intensiveness of invasion in 1958 was far higher than in 1959. Continuous examination carried out over a period of several years would give a fuller picture of seasonal fluctuations in the occurrence of the parasite. In comparison with the investigations made by Dryga s \& $\mathrm{P}$ i otrowski (1955) in three consecutive shooting seasons (November, December and January) from the same area and period a general increase in the intensiveness and extensiveness of invasion by this parasite can be noted. According to the above research workers the

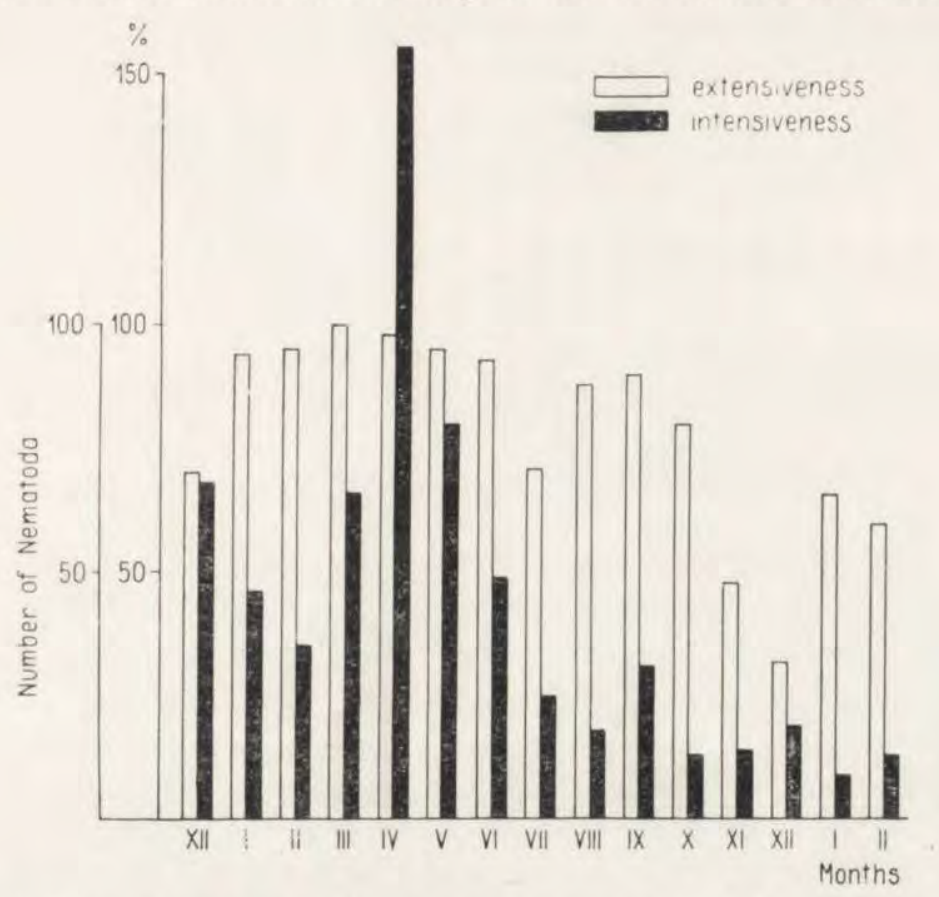

Fig. 3. Extensiveness and intensiveness of invasion by $T$. retortaeformis over the yearly cycle.

mean extensiveness of invasion by these nematodes was $55 \%$, the mean intensiveness approximately 50 specimens in one hare, while in our material the figures were respectively $61 \%$ and mean intensiveness about 310 specimens of the parasite in one host.

Dependence of invasion on the sex and age of the hares. Sex was determined in 592 hares. Out of 320 males examined $266(83.1 \%)$ were infested. The percentage of infested females was slightly lower: out of 272 examined $221(81.3 \%)$ had been invaded. The mean intensiveness of invasion was 531 nematodes in males, which is a slightly higher figure than in females, in which an average of 501 nematodes were found in one infected 
female. Over the yearly cycle extensiveness and intensiveness of invasion is slightly different in males and females. In males the maximum extensiveness of invasion occurs in February and March (100\%), in females in March and April (100\%). The decrease in extensiveness of invasion begins in both the sexes in October and reaches a minimum in December - in males $39.1 \%$, in females $26 \%$. Mean intensiveness of invasion attains its maximum in both sexes in April (1511 in males and 1730 in females), after which it decreases sharply and reaches a minimum in males in August ( 63 nematodes), but in the case of females not until December ( 53 nematodes) (Fig. 4). The delay in the decrease in invasion intensity in females

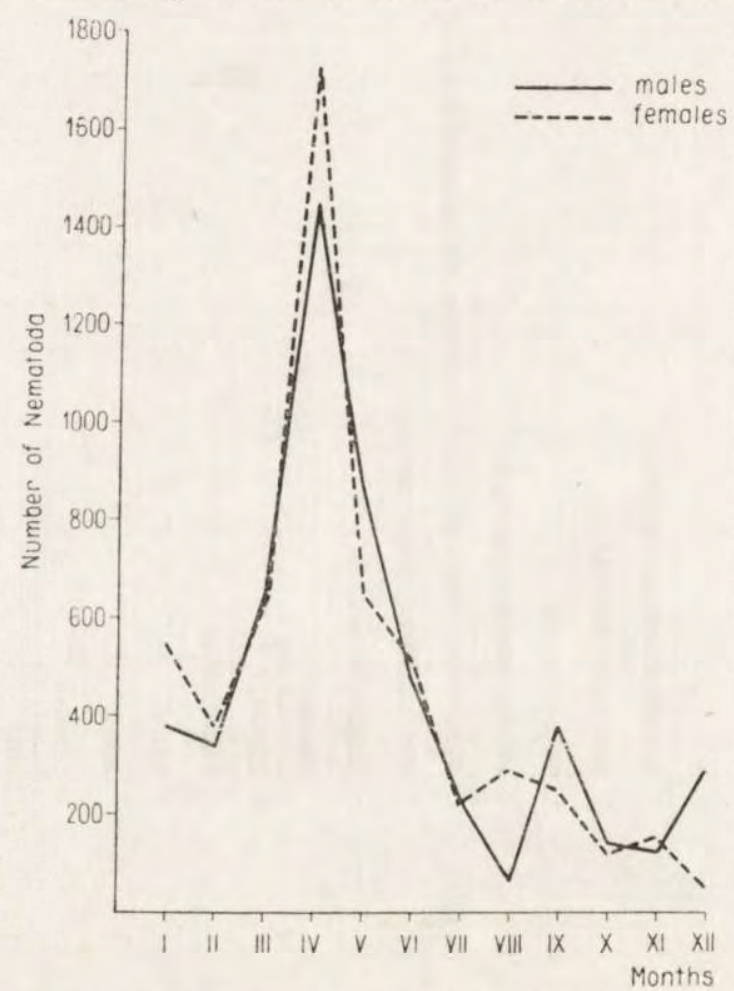

Fig. 4. Intensiveness of invasion by $T$. retortaeformis in males and females over the yearly cycle.

may be connected with the fact (accepted with some reserve as to the significance of these differences) that from January to September we encountered a considerable percentage of pregnant females, in which mean intensiveness of invasion proved to be higher ( 600 nematodes) than in non-pregnant females ( 565 nematodes) at the same time. Infestation by T. retortaeformis in the different age groups is illustrated by table 2 . The maximum extensiveness of invasion is found in hares one year old, and 
the minimum in young hares. Intensiveness of invasion follows a similar pattern although differences are less distinct in this case. The relations of these same age group in both sexes are somewhat different (Fig. 5). Extensiveness of invasion is almost identical in both sexes in different age groups, but intensiveness of invasion is markedly lower in young females than in young males (shown by thickness of column on the diagram). The

Table 2.

Extensiveness and intensiveness of invasion by $T$. retortaeformis depending on the age of the hares.

\begin{tabular}{|l|c|c|c|}
\hline Age & Young & Yearlines & Old adult \\
\hline No. of hares exanined & 150 & 147 & 257 \\
No. of hares infested & 96 & 146 & 229 \\
Extensiveness & $64 \%$ & $99 \%$ & $83 \%$ \\
Wean 1ntensiveness & 480 & 533 & 530 \\
\hline
\end{tabular}

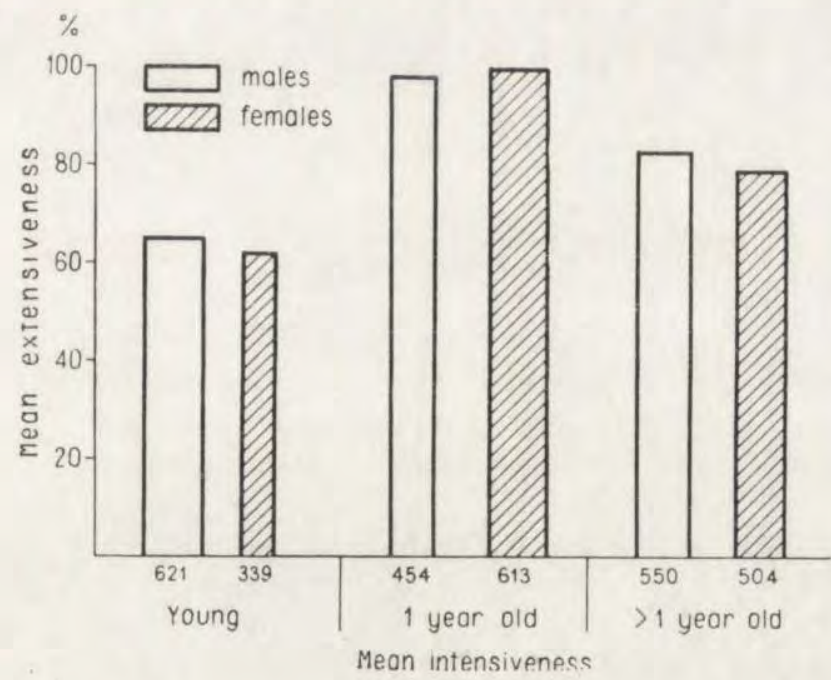

Fig. 5. Extensiveness and intensiveness of invasion by T. retortaeformis depending in the sex and age of the hares.

course taken by the invasion of $T$. retortaeformis in both sexes in the three age groups of the hares over the yearly cycle is illustrated by Fig. 6 . This diagram confirms the previous observation that variations in the intensity of invasion are connected with the season of the year. The maximum intensiveness of invasion was found in all the hares in April and May. This phenomenon is most distinctly marked in young males and females. Pregnant females form a separate group in which we wanted to 
trace the occurrence of $T$. retortaeformis, since we had collected suitable comparative material. During the period from January to September we examined 86 pregnant females, of which $80(93.7 \%)$ were infested, the mean intensiveness of invasion in the animals being 600 nematodes per

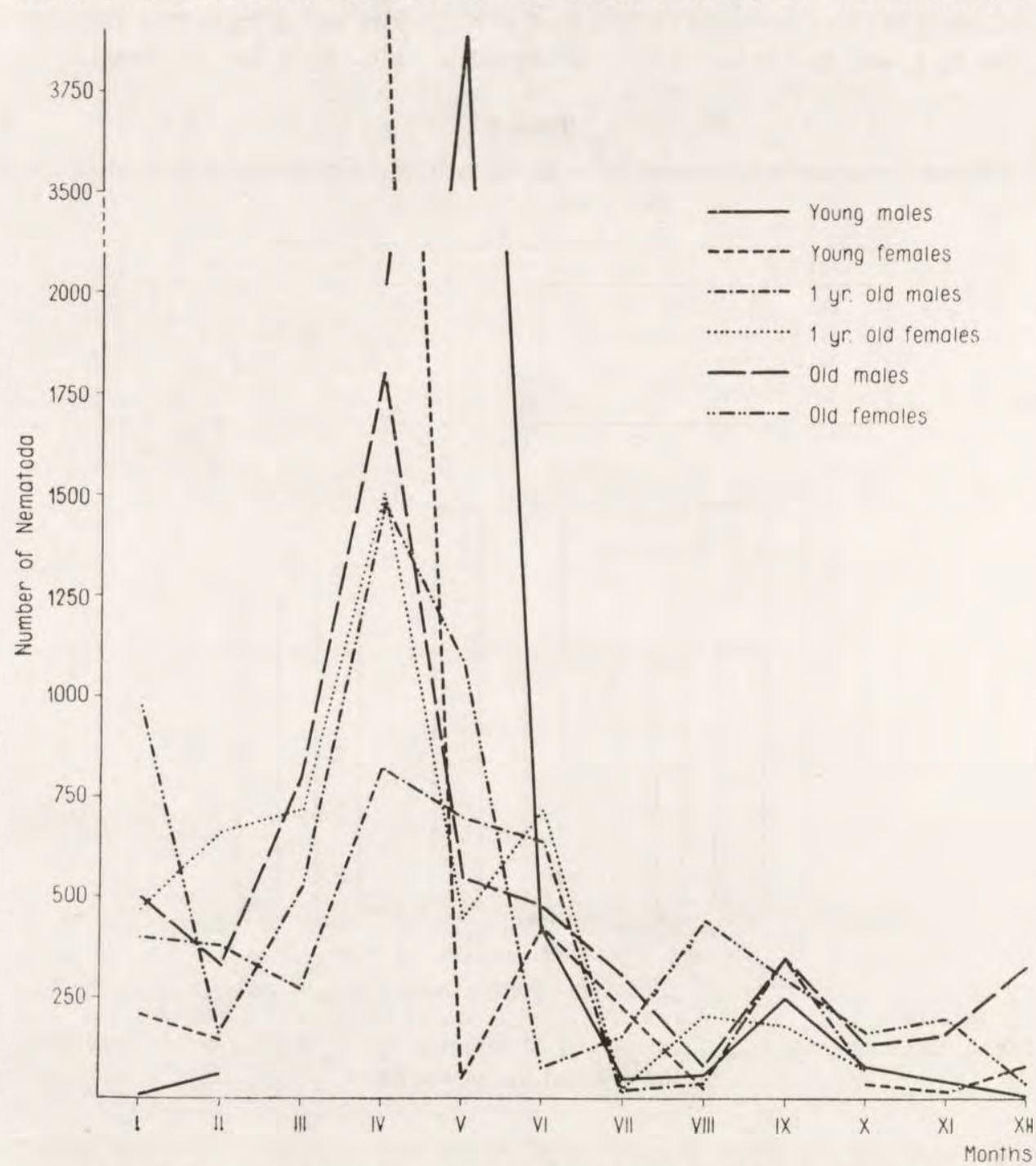

Fig. 6. Intensiveness of invasion by $T$. retortaeformis in yearly cycle.

female. Corresponding data for 186 non-pregnant females were $141(75 \%)$ infested animals and 450 nematodes per female. Both the extensiveness and intensiveness of invasion by T. retortaeformis is therefore lower in non-pregnant than in pregnant females. It is however necessary to em- 
phasise that non-pregnant females, examined over the course of a whole year, i.e. also during the period from October to December inclusive when there are no pregnant females, were used for comparison of the infestation of pregnant and non-pregnant females by $T$. retortaeformis. In view

Table 3,

Co-occurence of $T$, retortaeformis with other species of helminths.

\begin{tabular}{|c|c|c|}
\hline Species & $\begin{array}{c}\text { No. } \\
\text { of } \\
\text { hares }\end{array}$ & $\%$ \\
\hline T. retortaeformis - one-species invasion & 133 & 23.6 \\
\hline$T$. retortaeformis $+F$. hepatica & 3 & 0.53 \\
\hline$T$. retortaeformis $+T$. sylvilagi & 330 & 58.9 \\
\hline$T$. retortaeformis $+P$. terminalis & 2 & 0.36 \\
\hline T. retortaeformıs + G. strigosum & 9 & 16 \\
\hline$T$. retortaeformis $+M$. pectinata & 3 & 0.53 \\
\hline$T$. retortaeformis $+T$. sylvilagi $+M$. pectinata & 40 & 7.1 \\
\hline T. retortaeformis $+T$. sylvilagi $+T$. terminalis & 2 & 0.36 \\
\hline$T$. retortaeformis $+T$. sylvilagi $+G$. strigosum & 13 & 2.3 \\
\hline$T$. retortaeformis $+T$. sylvilagi $+F$. hepatica & 11 & 2.0 \\
\hline T. retortaeformis $+T$. sylvilagi $+A$. rhopalocephala & 9 & 1.6 \\
\hline T. retortaeformis + $P$. terminalis $+M$. pectinata & 1 & 0.18 \\
\hline$T$. retortaeformis $+T$. sylvilagi $+M$. pectinata $+A$. rhopalocephala & 2 & 0.36 \\
\hline T. retortaeformis $+T$. sylvilagi $+M$. pectinata $+G$. strigosumi & $\overline{1}$ & 0.18 \\
\hline$T$. retortaeformis $+T$. sylvilagi $+M$. pectinata $+P$. terminalis & 1 & 0.18 \\
\hline$T$. retortaeformis $+T$. sylvilagi $+F$. hepatica $+P$. terminalis & 1 & 0.18 \\
\hline Total & 561 & 100.00 \\
\hline
\end{tabular}

of the fact that it is during this particular period that a decrease occurs in the extensiveness and intensiveness of invasion, it is essential to accept a correction to the above statement, resulting from comparison of the infestation of non-pregnant and pregnant females only during the period from January to September inclusive. If then appears that the extensiveness of invasion in both the groups of females examined is almost identical, being $93 \%$ in pregnant and almost $92 \%$ in non-pregnant females. The mean intensiveness of infestation of non-pregnant females during this same period remains, however, slightly lower ( 565 nematodes) than in the pregnant females (600 nematodes) -- per one female. Such differences do not, however, justify the conclusion being drawn that the pregnancy of the host creates better living conditions for $T$. retortaeformis, since not infrequently completely opposite relations are observed, and in view of the considerable variations in intensiveness of invasion in different individual hosts the difference in the mean intensiveness of invasion would not appear in this case to be significant. The infestation of pregnant females is different in different age groups. In young hares and one-year old pregnant females we found $100 \%$ infestation, and in old hares $86 \%$, 
whereas the mean intensiveness of invasion was lowest in young females (205 nematodes), higher in one-year old hares (600 nematodes) and highest in old hares (720).

Co-occurrence of $T$. retortaeformis with other species of helminths. In the total number of 561 hares infested by $T$. retortaeformis there was a predominance of mixed invasion, as can be seen from Table 3 , which shows that in $58.9 \%$ of the hares there was mixed invasion by T. retortaeformis and T. sylvilagi, whereas there was one-species invasion in only $23.6 \%$. Mixed invasion by $T$. sylvilagi and $M$. pectinata came third in order of frequency of occurrence $(7.1 \%)$, while the remaining combinations of mixed invasion were only found sporadically.

\section{Trichostrongylus medius $\mathrm{O} 1 \mathrm{ig}$ e r, 1952}

We found one male of this species in the small intestine among numerous specimens of $T$. retortaeformis. The former species has been described so far in Lyrurus tetrix from the Soviet Union. The hare probably played the part of an accidental host in this case.

6. Graphidium strigosum (D u jar d in, 1845), R a illi et et Hen ry, 1909

The morphology of the specimens we found did not differ from the known descriptions of the species.

Localisation: stomach.

Intensiveness and extensiveness of invasion. We found G. strigosum in 28 out of 706 hares examined $(3.9 \%)$, in numbers varying from $1-72$ individuajs in one infested hare, with a mean figure of 9.4. The invasion of this nematode over the yearly cycle is shown in table 1 , from which it can be seen that this nematode occurred sporadically, with certain intervals, over the whole year. The low intensiveness and extensiveness of invasion did not permit of drawing conclusions as to the seasonal nature of the parasite's occurrence. It is interesting to note that we found relativeiy numerous specimens of the nematode in December 1958, January and February 1959, while during the same months of the following winter $1959 / 60$ we did not discover any invasion at all by this parasite.

Dependence of invasion on the sex and age of the hares. Sex and age were examined in all the 28 infested hares. Out of a total number of 330 males examined 17 were infested by $G$. strigosum $(5.3 \%)$, while amongst the 284 females examined only 11 proved to be invaded $(3.9 \%)$. The mean intensiveness of invasion, however, was found to be lower in males ( 5 nematodes) than in females ( 15 nematodes). Of the 11 females infested one 
was a young specimen, 2 one-year old and 8 older hares (including one pregnant female), while of the 17 males infested 5 were one-year old and 12 old hares. These data suggest that $G$. strigosum occurs more frequently in older hosts.

Co-occurrrence of $G$. strigosum with other species of helminths. Out of a total number of 28 hares infested, there was a predominance of mixed infestation:

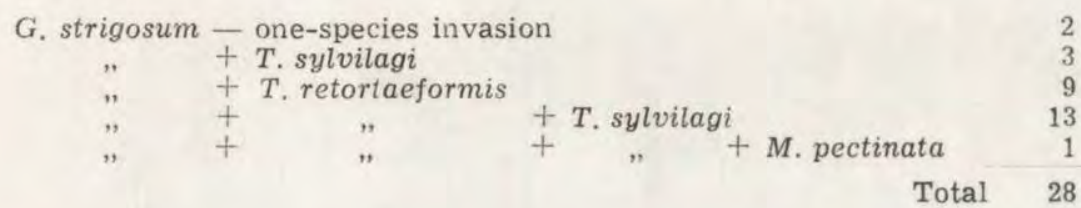

The above list shows that joint invasion by G. strigosum with $T$. retortaeformis and T. sylvilagi and G. strigosum with T. retortaeformis only was most frequently encountered.

\section{Haemonchus contortus ( $\mathrm{R} \mathrm{udol} \mathrm{ph} \mathrm{i,1803)} \mathrm{Cob} b, 1898$}

As in the case of Trichostrongyius medius, we also found only one male in the small intestine in the case of $H$. contortus. The hare has not hitherto been recorded as a host of $H$. contortus and is probably an accidental host of this parasite.

8. Protostrongylus terminalis ( $\mathrm{P}$ a s e r in $\mathrm{i}, 1884$ ) $\mathrm{K}$ a m e $\mathrm{n} \mathrm{s} \mathrm{k}, 1095=P$. commutatus (D i e s in g, 1851)

Morphology. In view of certain divergences in morphometric data for $P$. terminalis given by different authors, we have given below our own results of measurements made of 7 males and 11 females. The male was $23-35 \mathrm{~mm}$ in length and $0.13 \mathrm{~mm}$ in breadth, pharynx $0.36 \mathrm{~mm}$ long (after $\mathrm{H}$ a 11,1916 , from $\mathrm{S} \mathrm{z} \mathrm{u} 1 \mathrm{c}, 1932-0.665 \mathrm{~mm}$ ) ornamented spicula $0.16-$ $0.18 \mathrm{~mm}$ in length, telamon $0.044 \mathrm{~mm}$ in length. Female $-45-59 \mathrm{~mm}$ in length and $0.18-0.2 \mathrm{~mm}$ in breadth, pharynx $-0.42-0.45 \mathrm{~mm}$ in length, vagina $2.2-2.4 \mathrm{~mm}$ in length, distance from female genital pore to end of body $0.24-0.28 \mathrm{~mm}$, eggs oval $0.090-0.096 \times 0.060-0.080 \mathrm{~mm}$.

Localisation: bronchi.

Intensiveness and extensiveness of invasion. Of the 706 hares examined it was only in $8(1.1 \%)$ that we found invasion by P. terminalis, in numbers from $1-6$ individuals in one hare. Mean intensiveness of invasion was 3.5 nematodes in one infested hare. Over the yearly cycle we discovered invasion by $P$. terminalis in single cases, i.e. in $1-2$ hares in each month in January, April, May, June and August. 
Co-occurrence of $P$. terminalis with other helminths was as follows:

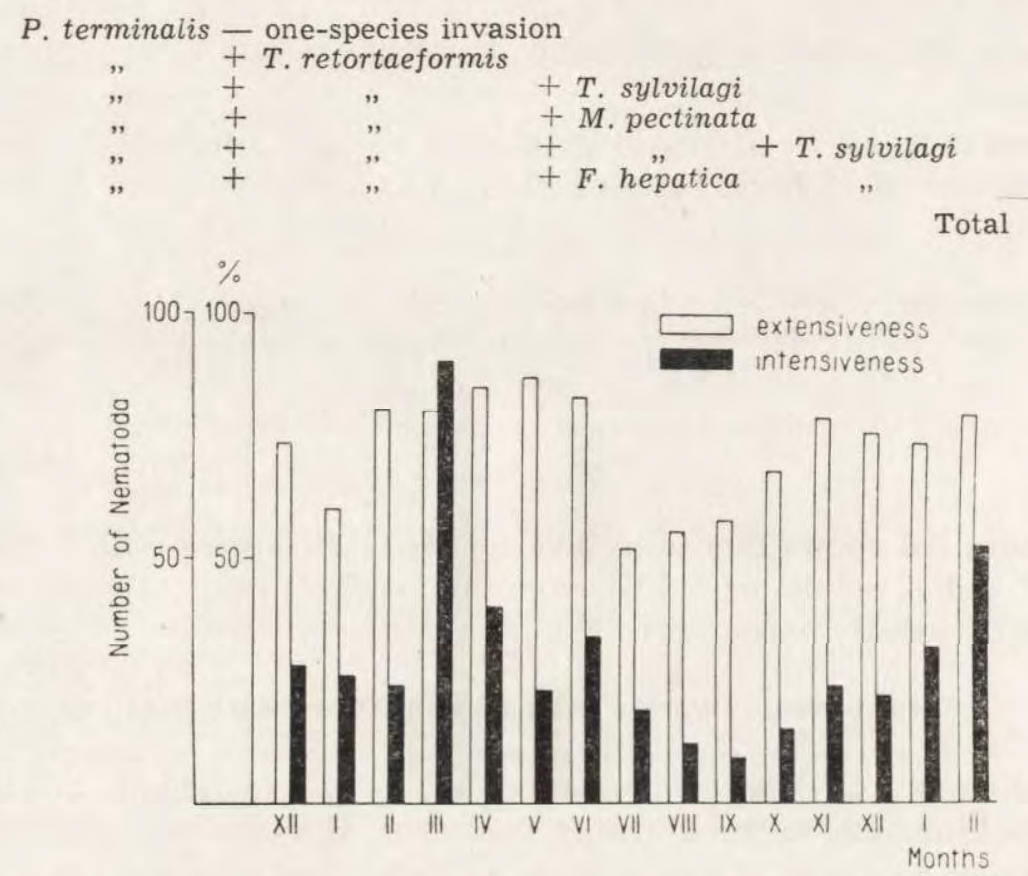

Fig. 7. Extensiveness and intensiveness of invasion by $T$. sylvilagi over the yearly cycle.

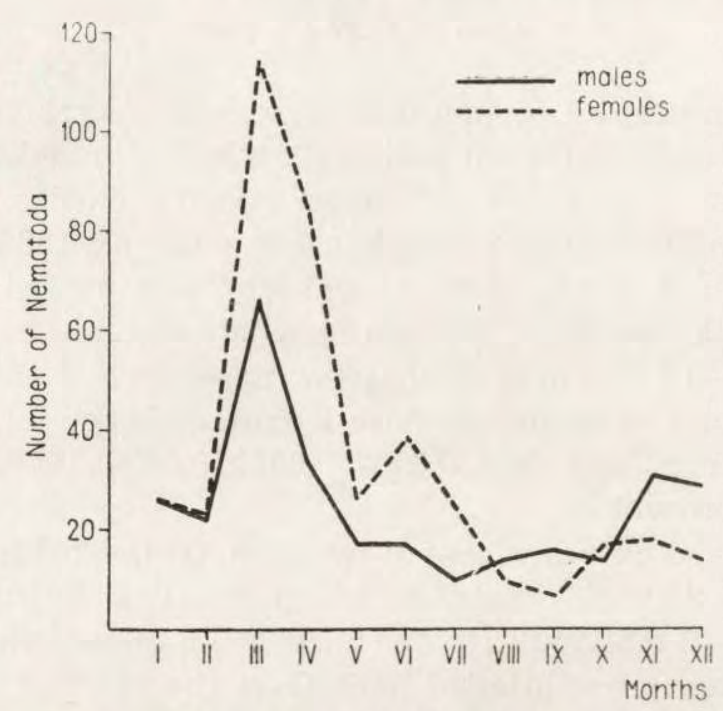

Fig. 8. Intensiveness of invasion by $T$. sylvilagi in the yearly cycle, depending the sex of the hares. 
Morphology. Of the morphometric data obtained in our material (50 males and 50 females) the following are worthy of note. Variations in length of the spicula from $5.6-8.2 \mathrm{~mm}$ (after Drygas \& P i otrow$\mathrm{ski}, 1955-6.5-8.8 \mathrm{~mm}$ ). Earlier research workers had not drawn attention to a character of importance in Trichocephalata, that is the structure of the pharynx. Our observations showed that the pharynx consisted of a very short muscular part about $0.5 \mathrm{~mm}$ long, while the number of stichocytes varies within limits of $60-73$ in males and $70-73$ in females. $\mathrm{T}$ i n e r (1950) in describing $T$. sylvilagi as a new species, based his description chiefly on the length of the spicula, which character makes it easy to distinguish $T$. sylvilagi from $T$. leporis, which has a short spicula (1.6-3.2 $\mathrm{mm}$ ). Earlier authors, who did not differentiate between these two species, classified them under the name of $T$. leporis, recording the existence of the armature of the spicular sheath and the vulva $(\mathrm{C} \mathrm{h}$ a nd le r, 1930; Szulc, 1931). Neither Tiner (1950) nor Drygas $\&$ P i otrow s k i (1955) refer to this character. As we had no specimens of $T$. leporis available we were unable to state whether the armature of the spicular sheath and vulva occur in this species. T. sylvilagi has a spicular sheath and vulva in which the armature consists of distinct spines.

Localisation: large intestine.

Intensiveness and extensiveness of invasion. We found T. sylvilagi in 514 out of the 706 hares examined $(72.8 \%)$, in numbers from $1-1230$ specimens in one hare. The mean intensiveness of infestation per one infested hare was 31.4 nematodes. Table 1 illustrates the state of invasion by the parasite over the yearly cycle, from which it will be seen that T. sylvilagi occurs abundantly throughout the year. Variations in intensiveness and extensiveness of invasion over the yearly cycle are more distinctly evident in Fig. 7, showing that extensiveness of invasion is maintained on a high level throughout the year, exhibiting fluctuations from $52 \%$ in July to $87 \%$ in May. During 1959 we observed a decrease in the extensiveness of invasion in the summer months (July, August, September respectively $52,55,58 \%)$ and an increase, greater in the spring months from March to May $(80-87 \%)$, and slightly smaller in the autumn-winter months from October 1959 to February 1960 (68-80\%). Fluctuations in the mean intensiveness of invasion do not coincide with the fluctuations in invasion extensiveness, but clearly point to the existence of a peak in March and decrease during the turning point between summer and autumn (minimum in September). In comparison with the results of the studies made by Drygas \& Piotrowski 


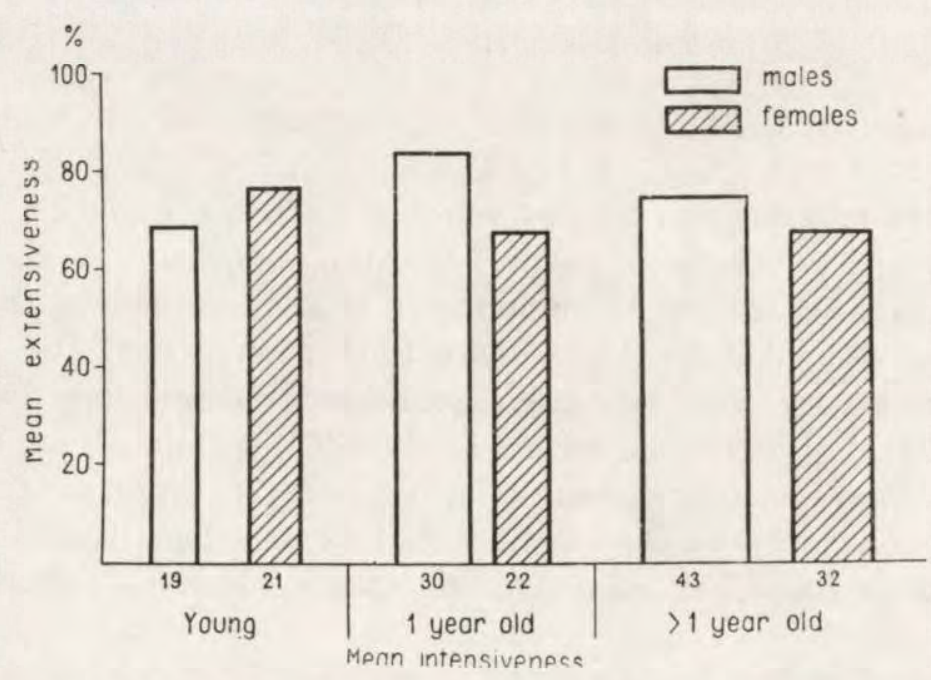

Fig. 9. Extensivenes and intensiveness of invasion by $T$. sylvilagi, depending on the sex and age of the hares.

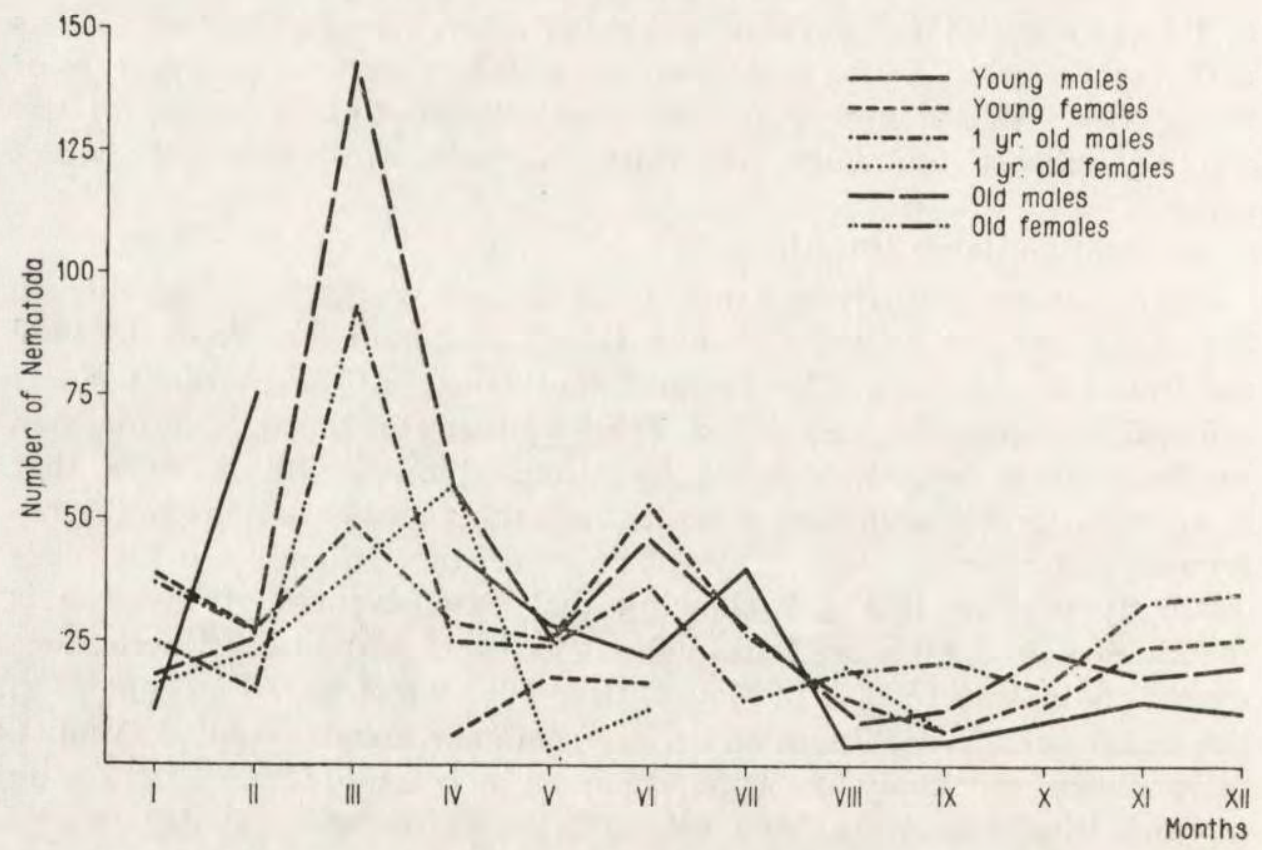

Fig. 10. Intensiveness of invasion by $T$. sylvilagi over the yearly cycle.

cur observations from the same period point to a similar extensiveness of invasion and slightly lesser intensiveness.

Dependence of invasion on the sex and age of the hares. Out of 320 males examined we found invasion by $T$. sylvilagi in $231(74.4 \%)$, and out 
of 272 females examined $190(70 \%)$ proved to be infested. Mean intensiveness of invasion was 32 nematodes per one hare in the case of males, and 27 nematodes in the case of females. It is therefore clear that both extensiveness and intensiveness of infestation by $T$. sylvilagi is slightly higher in males than in females. Over the yearly cycle the extensiveness of invasion by the parasite reveals no significant differences in either sex. Intensiveness of invasion, on the other hand, is markedly higher in males in the spring months (March-April) and summer months (June and July) than in females. As from August until the end of the year the reverse applies: mean intensiveness of invasion proved on the whole to be greater in females than in males (Fig. 8).

Age was determined in 572 hares. Infestation by $T$. sylvilagi in hares divided into three age groups is illustrated by Table 4 . This shows that extensiveness of invasion is almost identical in all the age groups. Intensiveness of invasion, on the other hand, increases slightly with age. Fig. 9 presents the intensiveness and extensiveness of invasion by T. sylvilagi in

Table 4.

Extensiveness and intensiveness of invasion by $T$. sylvilagi depending on the age of the hares.

\begin{tabular}{|l|c|c|c|c|}
\hline Age & Toung & learlings & 01d adult & Toto1 \\
\hline No. of hares examined & 150 & 147 & 275 & 572 \\
No. of hares infested & 108 & 111 & 195 & -414 \\
Extensiveness & $72 \%$ & $75 \&$ & $71 \%$ & \\
Hean intensiveness & 20 & 26 & 37 & \\
\hline
\end{tabular}

both sexes of hares divided into three age groups. It can be seen from this figure that in the group of young hares intensiveness and extensiveness of invasion is almost identical in both sexes, although slightly lower in males than in females, while in the remaining groups the reverse is the case: both these values are greater for males than for females. The question of whether the variations in intensiveness of invasion over the yearly cycle are connected with the season or with the sex or age of the hares was investigated (Fig. 10). From this figure it can be seen that the generally maximum level of mean intensiveness of invasion in March is accounted for by the old hares, both males (to a greater degree) and females (to a lesser degree). The absence of young males and females (less than a year old) in March made it impossible to compare infestation in the youngest and oldest hares at this time. In the remaining months of the year the intensiveness of invasion by $T$. sylvilagi is on the whole greater in one-year old and old hares than in the young ones. 
Pregnancy of females and invasion by T. sylvilagi. Out of 86 pregnant females examined between January and September 1959—63 $(73.2 \%)$ were infested. Out of the total number of 112 non-pregnant females examined cluring the same period we found infestation by $T$. sylvilagi in $67(59.8 \%)$. The mean intensiveness of invasion in pregnant females was 35 nematodes per female, whereas in non-pregnant females the number is 20. T. sylvilagi therefore occurs more frequently and numerously in pregnant females than in non-pregnant ones. This statement is also confirmed by an analysis of the state of invasion by $T$. sylvilagi in pregnant and non-pregnant females divided into age groups. In each of these groups both the percentage of pregnant females infested and the mean intensiveness of invasion by the parasite is higher than in the non-pregnant females.

Co-occurrence of $T$. sylvilagi with other helminths was as follows:

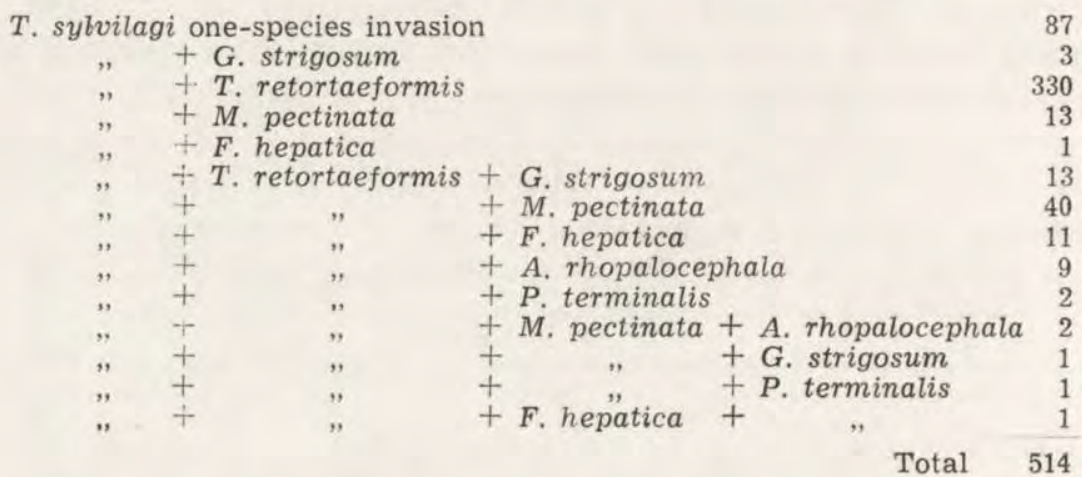

As can be seen from the above list we found $T$. sylvilagi most frequently jointly with $T$. retortaeformis, then in order of frequency, in the second place we found one-species invasion, and in the third mixed invasion with $T$. retortaeformis and $M$. pectinata. The remaining combinations of mixed invasion occurred in cases from $1-13$ in number.

\section{RESULTS}

\section{A. Morphological}

1. The anatomical structure of Fasciola hepatica from the hare does not differ from that of individuals found in the liver of cattle.

2. The differences, presented by Spassky (1951) in the dimensions of oncospheres and the shape and size of the prostate gland, supposedly making it possible to distinguish Andrya rhopalocephala from Andrya cuniculi would seem, in the light of our investigations, to be of no value for diagnosis on account of the individual variability of these characters. 
3. We several times observed in $T$. refortaeformis a symmetrical and lasting swelling of the cuticle at the anterior end of the body of T. retortaeformis, not recorded in any of the descriptions known to us.

4. We found differences in comparison with $\mathrm{H}$ a ll's (1916) data in the dimensions of the pharynx of male and female specimens of Protostrongylus terminalis.

5. In the case of Trichuris sylvilagi we established a degree of variation in the length of the spicula greater than that hitherto recorded and we drew attention to the armature of the spicular sheath and vulva.

B. Intensiveness and extensiveness of invasion over the yearly cycle

1. On account of their relatively rare occurrence it was not possible to arrive at any conclusions as to the seasonal character of invasion by F. hepatica, A. rhopalocephala, M. pectinata, G. strigosum and P. terminalis. Only in the case of $M$. pectinata did we find that it occurred throughout the year uninterruptedly, without discovering any significant seasonal variations.

2. We found strobilae with mature oncospheres in Andrya rhopalocephala and Mosgovoyia pectinata at different times of the year, which is evidence that winter destrobilisation does not occur in these species, at least not under Polish climatic conditions.

3. The maximum intensiveness of invasions is found in the case of $T$. retortaeformis in April, and of T. sylvilagi in March. During the peak period of intensive invasion the young males and females are most intensively infested by $T$. retortaeformis, and the old males and females by T. sylvilagi.

\section{Dependence of invasion on the sex and age of the hares}

1. Low extensiveness and intensiveness of invasion did not permit of reaching conclusions on the subject of the dependence of invasion by parasites on the sex and age of hares in the case of the following species: $F$. hepatica, A. rhopalocephala, M. pectinata, G. strigosum and P. terminalis.

2. Mean intensiveness and extensiveness of invasion is slightly higher in males than in females in the case of $T$. retortaeformis and $T$. sylvilagi.

3. Extensiveness of invasion by $T$. retortaeformis is lowest in young hares, higher in old ones and highest in one-year old hares. Mean intensiveness of invasion is slightly lower in young and almost uniform in old and one-year old hares. 
4. Extensiveness of invasion by T. sylvilagi is almost uniform in all three age groups, but intensiveness increases markedly with age: in young specimens 20 nematodes, in old ones 37 nematodes in one hare.

5. Comparison of infestation of non-pregnant and pregnant females during the period from January to September revealed an absence of differences in the extensiveness of invasion by $T$. retortaeformis in both groups $(92 \%$ and $93 \%)$. Extensiveness of invasion by T. sylvilagi was markedly higher in pregnant females $(73 \%)$ than in non-pregnant ones $(59.8 \%)$. The mean intensiveness of invasion by both species of parasites was greater in pregnant than in non-pregnant females, but there were significant differences only in the case of $T$. sylvilagi.

\section{Co-occurrence of helminths}

We did not find reciprocal exclusion of species of parasites infesting the hares examined. When analysing each species we most often found mixed invasions by Trichostrongylus retortaeformis and Trichuris sylvilagi.

\section{REFERENCES}

1. Czarnowski, A. \& Witkowski, E., 1954: Zapalenie pluc u zająca wywolane przez larwy Protostrongylus commutatus. Med. wet., 10, 2: 63-64.

2. Chandler, A. C., 1930: Specific characters in the genus Trichuris with a description of a new species $T$. tenuis from a camel. J. Parasit., 16.

3. Drygas, M. \& Pi otrowski, F., 1955a: Z morfologii Trichuris sylvilagi Tin e r, 1950. Acta parasit. pol., 2, 18: 343-359. Warszawa.

4. Drygas, M. \& Pi otrowski, F., 1955b: Materiały do fauny robaków pasożytniczych przewodu pokarmowego zająca Lepus europaeus L. Acta parasit. pol., 3, 15: 377-396. Warszawa.

5. Skrjabin, K. I., Sihobalova, N. P. \& Sulc, R. S., 1954: Osnovy nematodologii. III. Trihostrongylidy životnyh i čeloveka. Izd. AN SSSR. Moskva.

6. Skrjabin, K. I., Sihobalova, N. P., Sulc, R. S.. Popova, T. I., Boev, S. N. \& De la mure, S. L., 1952: Opredelitel parazitičeskih nematod. III. Strongylaty. Izd. AN SSSR. Moskva.

7. Spassky, A. A., 1951: Osnovy cestodologii. 1-286.

8. Š u I c, R. S., 1931: Parazitičeske červi krolikov i zajcev i vyzyvaemye imi zabolevanija. Selhozgiz. Moskva.

9. Tiner, J. D., 1950: Two new species of Trichuris from North America with redescription of $T$. opaca and $T$. leporis (Nematoda, Aphasimidia). J. Parasit., 36.

Folish Academy of Sciences, Institut of Parasitology,

Warszawa, Pasteura 3 .
Nedical Academy,

Department of Biology, Warszawa, Chałubińskiego 5 . 
Danuta CZAPLIÑSKA, Bogdan CZAPLIŃSKI, Maria RUTKOWSKA

\&. Danuta ŻEBROWSKA

\author{
BADANIA NAD ZAJACEM SZARAKIEM, IX. HELMINTOFAUNA \\ W CYKLU ROCZNYM
}

\title{
Streszczenie
}

\section{A. Morfologia}

1. Budowa anatomiczna Fasciola hepatica z zajęcy nie różni się ođ osobników stwierdzanych w wątrobie bydła.

2. Wysuwane przez S passkiego (1951) różnice dotyczące rozmiarów onkosfer ksztaltu i wielkości gruczolu kroczowego pozwalające rzekomo odróżnić Andrya rhopalocephala od Andrya cuniculi wydają się w świetle naszych badań nie mieć żadnej wartości rozpoznawczej ze względu na zmiennośé indywidualną tych cech.

3. U Trichostrongylus retortaeformis zaobserwowaliśmy kilkakrotnie symetryczne i trwałe wzdęcie oskórkowe przedniego końca ciała nie notowane $w$ znanych nam opisach.

4. U Protostrongylus terminalis stwierdziliśmy różnice w rozmiarach gardzieli u samców i samic w porównaniu z danymi H a lla (1916).

5. U Trichuris sylvilagi wykazaliśmy większą od dotychczas znanej zmienność długości szczecinek kopulacyjnych i zwróciliśmy uwagę na uzbrojenie pochewki spikularnej i wulwy.

B. Intensywność $i$ ekstensywność inwazji w cyklu rocznym

1. Ze względu na stosunkowo rzadkie występowanie nie można wnioskować na temat sezonowości inwazji $F$. hepatica, A, rhopalocephala, M. pectinata, G. strigosum i $P$. terminalis. Jedynie $M$. pectinata stwierdzaliśmy przez caly rok bez przerwy nie wykrywając istotnych zmian sezonowych.

2. U Andrya rhopalocephłala i Mosgovoyia pectirata znajdowaliśmy w różnych porach roku strobile z dojrzałymi onkosferami co świadczy, że destrobilacja zimowa nie występuje u tych gatunków przynajmniej w krajowych warunkach klimatycznych.

3. Najwiẹksza intensywność inwazji przypada dla T. retortaeformis w kwietniu, dla $T$. sylvilagi w marcu. W okresie szczytowego nasilenia inwazji najintensywniej zarobaczone są przez $T$. retortaeformis mlode samce i samice, przez $T$. sylvilagi zaś stare samce i samice.

\section{Zależność inwazji od płci i wieku zajęcy}

1. Mała ekstensywność i intensywność inwazji nie pozwala na wnioskowanie na tcmat zależności inwazji pasożytów od płci i wieku zajęcy dla następujących gatunków: F. hepatica, A. rhopalocephala, M. pectinata, G. strigosum i $P$. terminalis.

2. Sreỏnia intensywność i ekstensywność inwazji jest nieznacznie wyższa u samców niż u samic dia $T$. retortaeformis i $T$. sylvilagi.

3. Ekstensywność inwazji $T$, retortaeformis jest najniższa u mlodych zajęcy, wyższa u starych, najwyższa u jednorocznych. Srednia intensywność inwazji jest nieco niższa u mìodych a prawie jednakowa u starych i jednorocznych. 
4. Ekstensywność inwazji T. syvilagi jest niemal jednakowa we wszystkich trzech grupach wieku, jednak intensywność wzrasta wyraźnie z wiekiem.

5. Porównanie stanu zarobaczenia samic nieciężarnych i ciężarnych w okresie od stycznia do września wykazało brak różnicy w ekstensywności inwazji $T$. retortaeformis u obu grup $(92 \%$ i $93 \%$ ). Ekstensywność inwazji T. sylvilagi była wyraźnie wyższa u samic ciężarnych $(73 \%$ ) niż nieciężarnych $(59,8 \%)$. Srednia intensywność inwazji obu gatunków pasożytów była wyższa u samic ciężarnych niż nieciężarnych. Istotne różnice dotyczą jednak T. sylvilagi.

\section{Współwystępowanie helmintów}

Nie stwierdziliśmy wzajemnego wykluczania się gatunków pasożytów znajdywanych u badanych zajęcy. Analizując poszczególne gatunki najczęściej notowaliśmy inwazje mieszane z Trichostrongylus retortaeformis i Trichuris sylvilagi. 